\title{
Cruising on the Left: Notes on Genealogy of 'Left' Communication Research in the United States
}

\author{
Hanno Hardt
}

Communication research is typically identified with a mode of knowledge production that is firmly imbedded in the dominant ideology of society and responds to its needs and desires. As such it is an aspect of culture and cultural production that provokes questions about the impact of its knowledge and authority on everyday life.

Thus, (late) capitalism provides the ideological context in which communication research in the United States interacts with commercial or political interests in managing (and controlling) information-from the process of dissemination and the production of audiences to the effects of mass communication-to become an efficient instrument of social engineering. As such it assists with adjusting public communication processes, like news-making, advertising, or political propaganda in pursuit of the masses.

Ideological contrapositions, which imply radical changes for communication in civil society, on the other hand, are ultimately reflected in the engagement of "left" communication research-like in the struggle over democratizing the means of communication. Since a close relationship between theories of communication and society is widely assumed or desired, "left" communication research is presumably absorbed in "left" theories and practices of society.

This essay traces the idea of "left" communication research in the United States, with references to the writings and practices of American authors and critics of mass communication and in the context of historical developments from nineteenth century philosophical and theoretical influences to the rise of the New Left in the 1960s. Not unlike the Old Left, which never achieved holding political power and realizing its political goals_but whose ideas have made a difference in reforming American society_"left" communication research never dominated the research culture in the United States, but its contributions continue to enrich the landscape of communication studies.

The idea of "left" communication research is typically contained in the notion of "critical" communication research. Although potentially different (in terms of ideology), both share an understanding of communication as relations of power, which they address in their critique of the relations of media and society, for instance.

There is a tolerance of inclusion (of left perspectives) among those writing about "critical" communication research, like Leslie T. Good, who sees even a moral imperative at work in "critical" communication research on the demystification of power relations with the goal of creating a climate of interrogation among "critical" researchers (or theorists).[1] While Sue Curry Jansen writes about the implementation of a "media-critical" theory to suggest a broad based critique of media practices,[2] W. J. T. Mitchell's ideas about "dialectical pluralism," with its notion of "pushing divergent theories and practices toward confrontation and dialogue"[3] become the inspiration for the mission of a new journal, Critical Studies in Mass Communication. The work in a Marxist tradition of communication research, one thinks of Herbert Schiller or Dalles Smythe, for instance, remains isolated in its critique of society and reappears later with the rise of a Marxist tradition in a new and perhaps more hospitable environment of Cultural Studies, inspired by the work of Raymond Williams and Stuart Hall, in particular, and legitimized by their intellectual standing.

Mainstream—or traditional—communication research, on the other hand, represents a different understanding of communication, one that is compatible with the ruling ideology. The latter embraces relations of power for the 
purpose of creating and maintaining community or democracy by preserving a pluralism of shared responsibilities, or consensus in a Deweyan sense. Under these conditions of existence, communication studies describes representative relations of power among social, economic, and political or cultural institutions in pursuit of a common good. Its research practices are embedded in the positivism of the traditional social sciences and provide empirical evidence, whose decontextualized and ahistorical nature invites a growing critique during the 1980 s, in particular.

All the while "left" communication research is marginalized in the disciplinary discourse; it is either considered a foreign product[4] - based on European philosophical or theoretical propositions regarding democracy and society — or a Marxist project, which occupies only a fleeting moment in the American experience, when leftist ideas influenced the cultural and intellectual life of some communities before repression and the McCarthyism of the 1950s destroyed the sense of a collective mission.

Thus, U.S. American intellectuals of the left disperse during a changing political climate of widespread repression, [5] while in England, for instance, individuals on the left, who had abandoned the Communist Party, seemed to have remained together, published journals, and engaged in debates, while Latin American leftists united in the implementation of social projects, while drawing on European social thought.

Thus, there is no strong and continuing tradition of "left" communication research in the United States until the 1960s, when the potential of socialist ideas (and the tradition of the Old Left) are recalled, particularly with the rise of the New Left and the introduction of critical European thought on culture and communication.[6] This development - which encourages a decisively interdisciplinary outlook - is met with a growing curiosity by a new generation of scholars, who are to discover ways of demythifying dominant explanations of reality, including the role of media under capitalism.[7]

All the while, the "critical" tradition of communication studies continues to draw its strength and relevance from a pursuit of communication (and the press), in nineteenth century social thought. which extends into the progressive period of U.S. social history and involves an intellectual tradition that is broader than any particular discipline.

\section{I}

The designation of "left" communication research itself recalls the process of naming while setting up dichotomies, like left and right, or "subjective" (or tainted) and "objective" (or value-free). These designations imply not only an ideological bias, but, in fact, confirm the political nature of communication research-or the political purpose of research, in general-within a larger realm of civil society. But they also create an oversimplified understanding, especially of the nature of "critical" communication research, which often ignores the relation to politics, in particular.[8]

Hence, this essay is also about the process of naming as a historical practice; it raises questions about the meaning of names or labels, like "left" or "critical" communication research in the American context. And it traces the course of naming to provide a descriptive definition of the terminology and its implications, not only historically, but also for grounding radical thought and understanding contemporary practices in communication studies under conditions of political change.

Naming is a process of classification to come to terms with the objective world; it creates order according to specific interests or objectives. As much as it defines social and material relations, naming becomes also an articulation of power relations. When naming becomes a form of identification, "left"-in the context of a specific politicocultural environment_-denotes a particular political position, as in the case of "left" communication research. But generalizations abound, especially in the related discipline of sociology, where "Marxist" sociology, for instance, is occasionally equated with Communist sociology.[9]

Besides, to be "left" or "critical" may even become part of an individual's identity as a "leftist" or "critic," which has its own connotations and consequences in the specific historical moment, including the marginalization of individual efforts. Beyond the name, however, resides the actual practice of communication research-or the production of knowledge about communication (and media); a "critical" or "left" stance routinely provokes questions about the consequences of adopting the instrumental knowledge or authority of communication research for controlling social reality and offers alternative visions of existence.

The process of naming is subject to interpretation in the course of history however, and to shifts in meaning. Accordingly, terms like "left" or "critical" communication research have undergone changes during the last century 
or so and continue to be subject to modification as public or academic understandings vary or change with time.

Indeed, the term "left," which refers to a range of radical political views, originally is a metaphorical extension of the seating arrangement of the French Estates General (1789), when the Third Estate sat on the king's left, while the nobility occupied his right side. Divisions of opinions (regarding the royal veto) led to opposition by revolutionary deputies (on the left), with conservatives in favor and centrists seeking a compromise. Since then, politics has been perceived as a continuum of attitudes and opinions towards social change and social order (from left to right) with the parties on the left standing for change and those on the right for the status quo. This was some time ago.

Although the vocabulary has remained in use_-one still refers to left-or right-wing politics_clear distinctions, however, have faded. Thus, revolutionary thought or action regarding social change may be found on the right (in Nazism or Fascism, for instance), while conservative notions of order and protection of the status quo also characterize left-wing governments or parties (the Soviet Union, or the Communist Party). Additionally, any regime of the left or right has a tendency to move towards the middle, thus creating a left or right wing of its own, like the government of Tony Blair (UK), for instance, representing a modified political continuum that produces its own left of left opposition.

Hence, the term "left" communication research remains ambiguous regarding its relations to Marxism, at least in the United States, where it also falls within the wider use of "critical" communication research.[10] The latter is an inclusive term, whose usage refers to a broad ideological range of efforts to signal opposition to a dominant view of capitalism, democracy and media practices_-producing Marxist and non-Marxist versions of a social critique.

As such, the term "critical" is found more frequently in the pertinent literature than "left," since it is also a more ambiguous term, which allows for cover as it blends into a tradition of (literary) criticism, in particular. "Left," in the strictest sense of its normal use, suggests an unambiguous Marxist (research) perspective, whereas "leftist" becomes a derogatory expression used to discredit critique of any kind. In more practical terms, the use of these terms in American communication studies suggests that "left" communication research is always "critical,"while "critical" communication research is not necessarily "left."

Because of fundamental shifts in the ideological landscape of modern politics, it is important to define and understand the rise of "left" research[11] in the context of specific political ideas and/or movements during a specific historical moment of civil society.

\section{II}

Thus, the first phase of "left" research is introduced to European, or Western social thought with the nineteenth-century writings of those political economists, in particular, who had grasped the significance of modern communication, and the role of the press, specifically, in the emergence of a bourgeois society. Rapidly advancing European publics, where civil society rather than the state becomes the focal point of developmental issues, are defined in terms of social communication vis-à-vis commerce and politics.

Beginning with Karl Marx's interrogation of press freedom, specifically, and spreading across several generations of political economists and sociologists (from Albert Schäffle to Karl Bücher and later from Ferdinand Tönnies to Max Weber), the German academic scene displays a strong and determined interest in the role of communication and media in society.[12] Their American students, like Albion Small in particular, translate these concerns in their own work and address the significance of the press and the importance of social communication, in general.[13] However, Small and other founders of American sociology never subscribed to radical ideas (like socialism or Marxism) and their reformist ideas faded with the increasing industrialization of culture. C. Wright Mills observes in the 1950s that "sociology has lost its reformist push; its tendencies toward fragmentary problems and scattered causation have been conservatively turned to the use of corporation, army, and state."'[14]

By recognizing communication as central to political progress and social change, these thoughts throughout the century help establish the agenda for early twentieth century sociological research; they eventually contribute to contemporary "left" communication research with warnings about the power of the press in making or changing public opinion, about the problem of commercial versus public interests in utilizing the means of communication, and with predictions about increasing public reliance on the media (the press) for shaping and delivering fact and fiction.

In doing so, they also offer the first sustained critique of the press as an instrument of social and political 
change (in the hands of plutocrats) and determine the danger of ownership without responsibility. These writings constitute the first historical window on the potential of social research that opens during the early years of the twentieth century with an outlook on a critical agenda for radical positions in political economy and sociology on communication in society.

There is, however, no sustained or systematic presence of Marxist scholarship in U.S. communication studies since the nineteenth century, and there is no "left" influence on mainstream communication research until after World War II, and the 1960s specifically. Without expanding on the earlier writings of liberal scholarship, it should be noted, however, that critical thinking about social communication, and specifically about the institution of journalism as a dominant force in structuring everyday realities, coincides with the onset of social and political change in Europe with the end of World War I. In the United States, a period of repression begins after events in Russia and Germany, in particular, when middle-class nativist intolerance rises with fear mounting that foreign radicals would create a revolutionary atmosphere in the country.[15]

The press, in particular, becomes a politically important and commercially desirable property with its rich potential for defining relations between state and civil society and the attitudes of individuals, while being able to proclaim a defense of democratic principles, including freedom and individual values—or of the American way.

Criticism of these developments culminates in the work of American intellectuals like Upton Sinclair, George Seldes, Harold Ickes, and Oswald Garrison Villard,[16] among others. Yet, except for Sinclair, the critique of journalism as performance never leaves the realm of collective self-criticism to radically challenge the dominant ideology. They are joined by John Dewey [17] and Walter Lippmann,[18] whose own critical views of mass communication in twentieth century society are firmly grounded in a liberal-pluralist perspective. Also, magazines like The Nation, American Mercury, Commonweal, The New Republic, and Atlantic Monthly carry a critique of journalism beginning in the 1920s.

In the 1930s specifically, American writers of the left had begun to attack the brutality of capitalism and embrace the cause of labor, which results in an outpouring of proletarian novels with a built-in critique of the political system. [19] After all, the world was changing, and how could anyone "after a diet of Ibsen, Nietzsche, Bergson, Wells, Shaw, Dostoevsky, and Freud ... accept bourgeois moralities uncritically?”[20]

Indeed, the theoretical or philosophical grounds of "left" communication research must be sought in the company of a much broader, intellectual quest for social and political reform, if not revolution, that is shared by some writers and social thinkers earlier in the twentieth century. In this politicized literary environment, "critical" communication research, on the other hand, becomes identified historically with cultural criticism before mainstream communication research, following sociology, turns into a narrow, social-scientific pursuit of knowledge about media and communication led by progressive sociologists in the 1940s.

The cumulative work of these authors, and others,[21] is an example in tone and scope of commercial and scholarly examinations of media practices in the years to come, crowned perhaps by the Hutchins Report in 1947, which remains the most extensive and systematic, highly critical and yet ideologically faithful assessment of media practices in the United States to date.[22]

Whatever reform-minded or "left" research existed before World War II, however, disappears with the engagement of "left" intellectuals in the war effort (against Germany and Japan) and psychological warfare research. This turn away from ideologically "left" positions on media and society, or on the nature of democracy-the latter is always at the heart of "left" research—raises its own questions about the attitudes of radical social thinkers or social scientists—like Leo Lowenthal, Herbert Marcuse, or even Paul Lazarsfeld, among others—as they function for some years in an official environment that demands not only political support of the war effort, but compliance with dominant social scientific theories and methodologies.

In fact, the presence of postwar mass communication research reflects an era of certainty that appears with the development of a sophisticated social scientific apparatus, including research methodologies. It is the outcome of an accelerated development in science and technology and complements the political-military success of the United States in world affairs. Its reliance on the reign of facts reveals an irresistible bias towards the production of tangible social and political information. The emergence of public opinion polling with its confidence in methodology and faith in prediction reflects the endless possibilities of an applied science that serves the goals of commercial and political interests. It also legitimizes the ahistorical and decontextualized nature of such practices-which focus on information rather than knowledge - to seek solutions in immediate response rather than delayed explanation. They are reproduced prominently in the journalism and advertising of the day. The wartime detour through government 
institutions hardly advanced the cause of "left" research and demonstrates the fragile nature of radical positions at any time in history. Indeed, the wartime episode of research in support of military and government intelligence work not only bolsters the institutional credibility and academic viability of communication research, but provides financial independence through continuing government contracts and confirms the place of journalism and mass communication studies in the university environment. The subsequent Cold War period becomes another testing ground for definitions of "left" communication research vis-à-vis socialist theories and practices of Eastern European, Cuban, or Chinese societies, in particular. But Soviet-style socialism, for instance, is generally met with skepticism or ambiguity in its execution of communication practices.

This takeover of communication research (identified with mass communication or journalism programs) by government interests is similar to the identification of Germany's Zeitungswissenschaft with the research interests (in propaganda) of the Nazi regime, or to the development of cadre schools in East Germany after World War II. In each case, governments reinforce academic credibility, dictate research agendas, and, therefore, influence the intellectual demands on the field, while distracting from the potential of criticism represented by "left" and "critical" communication research.

In the United States, (funded) communication research proceeds to support commercial and political interests in dominating the process of societal communication. Its focus on effects studies within an ideologically predetermined concept of democracy is a direct extension of wartime practices among the social sciences.

\section{III}

This is the point in time, when the second phase of "left research," and "left" communication research, in particular, emerges together with the rise of the American New Left during the late 1950s and early 1960s. The New Left, consisting of a variety of political and social movements, crystalizes in opposition to U.S. intervention in Vietnam, with student disaffection regarding a self-serving, corrupt bourgeois society and a loss of confidence in the Old Left (for reasons of effectiveness and ethics). It is an uneasy alliance of radical student groups, peace activists, early feminist organizations, as well as intellectuals with communist, socialist, or anarchist leanings. Their shared interests in a radical critique of "the system" - meaning capitalism—and in a new form of "participatory democracy" constitute a collective agenda of sorts that sustains the attempts of the movement for some time to create the condition for significant changes.

The arrival of left politics, particularly in Europe, but also in Latin America, was accompanied by attempts to retheorize culture (including the role of media and communication) in socialist politics concurrent with re-readings of a number of Marxist writers, among them Georg Lukács and Antonio Gramsci, but also Jürgen Habermas, French structuralists (Louis Althusser), and exponents of British Cultural Studies representatives (Raymond Williams, Stuart Hall), and Critical Theory (Horkheimer, Adorno, Marcuse, Fromm).

The result, however, does not strengthen revolutionary politics in the United States, in the long run, and the process merely exhausts itself with considerations of "the subject" at the expense of collective political goals. Terry Eagleton describes this development as a shift from politicized culture to cultural politics.[23]

However, these philosophical/theoretical debates do produce an ideological framework for "left" research with which to address the social, ecological or political concerns of the New Left. When its distrust of the system is articulated by "left" social research, a broad range of topics emerges, typically focused on the construction and control of the cultural environment. This includes the social and political impact of popular culture, its effect on the working class, and the entrenched media uses by a dominant power structure within a broader discussionespecially in Marxist historiography-which, according to Eric Hobsbawm, focuses on "the broad nature of social and economic formations in general and the transition from feudalism to capitalism in particular." [24]

In the U.S. American context, communication studies becomes aware of its connectedness to a much larger historical-cultural environment and, therefore, to a politically significant socio-political realm. Elsewhere, like in the Latin-American context, however, communication research had always been considered one aspect of a more comprehensive social and political project of the Left that explores the relations between communication as power and culture for social and political undertakings. Hence, the alignment of (mass) communication research and politics forms a combative agenda of democratization. Indeed, Latin America harbors theories and demonstrates practices of "left" communication research in several national settings since the 1970s.[25] Their examples, set internationally 
by the McBride Report, the definitional work on cultural imperialism, and various UNESCO initiatives, had little impact on the making of U.S. "left" communication research, however, thus confirming the privileging of AngloEuropean ideas and the neglect of theoretical impulses from Latin America.

More recently, a critical tradition of inter-Asian communication research has emerged (with Myungkoo Kang/ Seoul and Kuan-Hsing Chen/Taipei) with the publication of Inter-Asian Cultural Studies (1999), which focuses on the "critical inter-asia subjectivity" for the benefit of regional scholarship.[26] Here the notion of "critical" involves Marxist and non-Marxist perspectives on culture and media.

In this global context and in the specific atmosphere of radical history and New Left politics in the United States, "left" communication research emerges to raise questions about access to the means of communication, while focusing on the relationship between participation and democracy. Its rise profits from the lively, praxis-oriented debates of the time in other disciplines and translates the demands for critical or radical critiques of the system into research agendas that begin to question the dominant definitions and uses of media, their relations to political and commercial interests, including their participation in state-sponsored economic and political interventions abroad.

The New Left provides "left" communication research with the tools or visions, from radical or Marxist feminism and the black struggle for civil rights, to fuse issues of gender, race, and class into a socially and politically determined quest for knowledge about the relations of communication and contemporary society. Indeed, the New Left, according to Alvin Gouldner, speaks in "a deliberately utopian voice of Freedom Now, while Functionalism has never centered its interest on freedom or on equality, but has rather invested itself in order and social equilibrium."'[27]

Indeed. the discursive shift in the late 1960s produces a new understanding of communication as central to grasping the nature of society, for instance, and reveals alternative perspectives by introducing a number of useful options to rethink the notion of communication as information. Thus, it is no accident that during the latter part of the 1980s refocusing on the "critical" in communication studies becomes more widespread. At the same time, mass communication (or journalism) as a field of study is looking for new ways of understanding its own history and meeting the challenges to its traditional paradigm. In addition, continued accessibility to the cultural discourse in Europe-including a sustained critique of capitalism—also stimulates alternative thinking about communication, which addresses directly concerns of traditional mass communication research related to the role and function of media in society with theoretical contributions containing the potential for a major paradigm shift. For instance, the previous notion of information society undergoes an ideological critique when the idea of communication is reintroduced via British Cultural Studies—or "left" communication research—as a viable, if complex concept of human practice. In fact, the idea of communication is related (again) to human agency and the emancipatory struggle of the individual. Moreover, the discursive shift offers alternative ways of conceptualizing society, the public sphere, and the nature of democratic practice itself. It is based on an understanding of a historically grounded reality of institutions and practices that can be grasped, interrogated, and reconstructed through a dialectical process.

\section{IV}

In the American context, a visible split emerged between traditional, empirical research practices that were aligned with state or commercial interests and a new, critical research tradition that began to question and challenge the dominant system of mass communication. The result, however, was an oppositional rather than a "left" stance within a liberal tradition treminiscent of the progressive era and the work of its various social critics. The assessment of different social and political institutions, for instance, never endangered the philosophical foundations of "the system." It served a maintenance function rather than a radical agenda for change in the American system of power relations. Hence, E. P. Thompson talks about American elements of the New Left, who were actually "a revolting bourgeoisie doing its own revolting thing - that is the expressive and irrationalist, self-exalting gestures of style that do not belong to a serious and deeply rooted, rational revolutionary tradition."'[28] Indeed, it has been noted elsewhere that "what passed for Marxist thinking could be more accurately placed somewhere between the margins of Progressive thought—Charles Beard, V.L. Parrington and John Dewey—and a rough understanding of Marxian economics" with the result that in times of political change, authors returned "chastened, almost without exception, to the familiarity and warmth of mainstream American thought: on one side to the pragmatism and empiricism of the social sciences; on the other, to the aestheticism of high culture." [29] Also, a number of liberal sociologists, among them: Nathan Glaser, Daniel Moynihan, Lewis Coser, Dennis Wrong, Irving Horwitz, and Howard S.Becker "could 
have been regarded as radical, without being systematically challenged on this point,"according to Schwendinger and Schwendinger. [30]

The differences were most clearly manifest in the split between empiricism and critical theory and effectively articulated for communication research by Paul Lazarsfeld. His classic essay on administrative and critical research,[31] acknowledges a place for critical communication research, citing Max Horkheimer's ideas of developing a theory of prevailing social trends and appraising all actual or desired effects based on the need to preserve dignity, freedom, and the cultural values of human beings. Lazarsfeld foresees a combination of administrative and critical research, although primarily for the enrichment of his own interests in administrative research rather than for joining in a challenge of the dominant ideology and its communication research interests. While his acknowledgment of Critical Theory — as he understood it—suggests the relative effectiveness of Horkheimer's and Adorno's ideas and becomes somewhat of a rallying idea for later proponents of "critical" research, it fails in the context of its time to make a significant difference in the approach to communication research in the United States. The article is frequently cited in defense of "critical" communication research, yet rarely questioned for its failure to incorporate critical ideas into the dominant research paradigm. [32]

And yet, even social criticism within the dominant paradigm of mass communication research becomes problematic at the point of publication. For instance, when the issue of "critical" research emerges more substantially in the Journal of Communication (1983) entitled, "Ferment of the Field," the well-intentioned publication never articulated a socialist position beyond a mere acknowledgment of Critical Theory or neo-Marxist perspectives, and utterly failed to engage the field in any significant debate regarding the past, present, or future of "left" communication research. Although some authors refered to alternative methods of inquiry, they remained vague when using terms, like "critical" or "European-style" research, which implies analyses of power and control. Their references, however, did point to the growing interdisciplinary nature of communication research. The editor, George Gerbner, ultimately manages to collapse Marxist positions into an extended notion of "critical scholar" by including all of those who struggle to address the terms of the discourse and the structure of knowledge and power.

The weakness of a "left" communication research tradition is also confirmed by a more general lack of community. Except for the Union of Democratic Communication (1981), a shelter for even radical positions on issues of communication and society, there are no academic or professional groupings of "left" communication scholars.[33] Also, there is no tradition of radical, "left" journals in the field of communication studies, like in other disciplines, if one thinks of Radical History Review (1973), Radical Teacher (1975), The Insurgent Sociologist (1969), or The Review of Radical Political Economics (1961), among others.

In fact, the well-intentioned emergence of Critical Studies in Mass Communication (1984) illustrates the failure to provide a platform for "left" research or debate.[34] Even the successful, graduate student initiative with the Journal of Communication Inquiry (1974) at the University of Iowa does not have a sustained record of "left" research. Both journals may have attracted some "critical" research, yet without a decidedly "left" perspective on issues of communication, media, and society.

The recent publication of Canonic Texts in Media Research offers yet another insight into a mainstream, historical treatment of Critical Theory and British Cultural Studies; the latter become part of an attempt of grounding the field in the philosophical/theoretical writings of various "schools." Their selective rather than comprehensive interpretation (from British, American and Israeli perspectives) yields no acknowledgment of any school of "critical" or "left" communication research, indeed, there is no integration of Critical Theory and British Cultural Studies into the intellectual history of American media research except as intellectual challenges, which neutralizes these writings ideologically and politically. By focusing on their role as "canons," or institutionally grounded texts, the writings become "search engines" for intellectual pursuits, according to Elihu Katz.[35] Hence, "left" media research in the United States remains hidden and even disconnected from the original writings or historical circumstances as it is set adrift in this interpretation of the intellectual history of communication studies.

The developments since the mid-twentieth cenrtury underscore the observation that form and effects of communication have become more important than the politics of communication research among those critically engaged in a study of communication. Indeed, while American sociology invents "good sociology," [36]—a reminder of Lester Ward's positivistic "pure sociology" — and promotes the detached pursuit of scientific knowledge, mainstream communication research at the time pushes on with its agenda of effects studies-based on liberalfunctionalist theories — without any direct confrontation with "critical" research practices. Indeed, there is no Pitirim Sorokin, C. Wright Mills or Norman Birnbaum (among others)[37] in mass communication studies, who will remind 
colleagues forcefully of the pitfalls of their conceptualizations of the field of study.

But then, (mass) communication research is neither a discipline, nor does it have a time-honored intellectual tradition or a strong academic standing among other disciplines. In fact, its accomplishments are modest. It is worth remembering during these times of paradigmatic shifts, how little knowledge of (mass) communication has actually been gained by traditional social scientific studies during the last century. Much of what is known today about the role and function of media, for instance—or of the notion of effects, in particular, and the process of mass communication in society, in general-has been understood (and discussed) for centuries by generations of intellectuals, whose creative insights quickly revealed the workings of any (new) cultural phenomenon in their midst-from pre-Socratic rhetorical scholarship to nineteenth century thought about the political economy of the press, for example.[38]

In the meantime, the recent turn to "critical" alternatives represents an opportunity for traditional research practices to benefit creatively from the discourse of Marxism, Critical Theory, or Cultural Studies as "intellectual challenges" and/or methodological alternatives; there is no exploration (or perhaps even understanding) to date of the role of ideology and the relations of epistemology and politics in an alternative, or even radical brand of communication research. In fact, the intellectual history of American (mass) communication research is marked by a resistance to theory and a preference for models and quantitative methods. The former simplify reality-or the process of communication-in order to understand it; the latter tend to decontextualize and isolate historical phenomena (like in survey research or content analysis).

On the other hand, for mainstream communication research to realize the potential contribution of Critical Theory to a critique of contemporary society, it needs to explore the rise of Critical Theory in the political and cultural context of Weimar Germany and its criticism of mass society in the United States.[39] The decisive elements for this analysis are the attempts of critical theorists to replace the preoccupation of traditional philosophy with science and nature by shifting to an emphasis on history and culture, with an acute awareness of the relationship between epistemology and politics.

While Critical Theory - particularly with its cultural pessimism (Adorno and Horkheimer) —had found little resonance in communication research, British Cultural Studies with its focus on popular culture, its contemporariness, as well as its more accessible language, reaches a new generation of communication scholars, who are willing to experiment with a new perspective on communication and culture and to respond to Raymond Williams's call for a participatory culture. It includes the early efforts by Lawrence Grossberg, in particular, to popularize an American version and introduce a Marxist view of the politics of textuality.[40] More recently, the emergence of a Critical Cultural Studies approach in reaction to the previously domesticated version of British Cultural Studies suggests a decisive shift to a more critical position on issues of culture and communication.

\section{V}

There is yet another, more domestic version of "left" communication studies, however, that emerged with the work of Herbert Schiller and Dallas Smythe (or Tom Guback) on a political economy of the media. In fact, their contributions constitute a sustained "left" research effort that became the most promising source of a "left" communication studies tradition in the United States.[41]

More specifically, Schiller's work as an interventionist has been the crusade of a humanist, who believes that a heightened consciousness may eventually lead to desperately needed social changes. Smythe offers a politicaleconomic perspective, steeped in historical materialism, that focuses on information control, audience commodities, and a general critique of mass communication research and theory. Both demonstrate through their work the potential for Marxist criticism beyond the 1960s.[42] Their pursuit receives additional support with the availability of a more current, critical political economy of the media in Britain, which reinforces U.S. American efforts.[43]

Both, British Cultural Studies and a political economy of the media offer different, yet suitable examples of new approaches to "critical" communication research; they grow out of New Left concerns and reflect an appropriation of Marxist thought. By contextualizing (mass) communication in the specifics of politics, specifically, "left" communication research is called upon to engage in social, economic, and cultural diagnoses of societal communication. Focusing on the social consequences of cultural processes-including communication-will marginalize the narrowness of traditional effects studies, while a political economy of the media reveals the complicity 
of the culture industry and its impact on every day life.

In other words, "left" communication research—by identifying with British Cultural Studies_considers the idea of culture an appropriate site for explaining mass communication. Beyond it, however, lies an abiding interest in a social and political critique of society and the role of economics in a mediated public life.

Individual efforts to maintain a "critical" research agenda on the margins of the field have been reinforced in the past — at least partly — by educational efforts at the universities of Illinois, and Iowa, in particular, where the inclusion of historical and cultural perspectives — and qualitative methods_-helped introduce a more systematic approach to alternative, ideologically differentiated perspectives on communication and media.

However, the cadre schools of empirical communication research (e.g., Minnesota, Michigan State, and Wisconsin, in particular) continued to dominate the major research institutions in the United States — with faculty appointments well into the 1990s — and control the research discourse in pertinent journals and professional meetings.

\section{VI}

With the impact of Cultural Studies on issues of media and communication and a focus on a political economy of the media, "left" communication research joins in the destabilization of intellectual boundaries. The emerging interdisciplinary perspective-which includes literature, anthropology, ethnography, economics, as well as sociology, psychology, and social philosophy - is a liberation from confinement in a rigid disciplinary tradition. It is also an opportunity for embracing a host of cultural insights into social communication as individual routine and collective practice and for implementing a variety of methodologies. For instance, grounded in historical consciousness, "left" communication research introduces history as method to expose the importance of power and confirm the significance of human agency for communicative practices with the goal of transforming specific social, political, or economic conditions for the purposes of social and political change and emancipation, in general.

The resulting practice of theory and research reflects the workings of a critical consciousness on issues related to the privileged and authoritative knowledge of mass communication research and contributes to a blending of the humanities and social sciences as a major intellectual project of recent years. Contemporary writings about communication and culture explore these extensions and offer evidence of "critical" mass communication research as a blurred genre among signs of a more radical break with tradition. The turn towards the left occurs at a time, when the search for answers to existential issues - hitherto focused on articulating the function of (mass) communication in society in the jargon of the social sciences - had reached an impasse of considerable proportion. The social scientific discourse is trapped among fragmented empirical foundations of age-old pronouncements about the state of social communication and incapable of moving beyond a professional vernacular that has dominated mass communication research for decades. Communication theory must be driven by a strong utopian mentality, to speak with Karl Mannheim - which is oriented towards the realization of a new mode of public communication that reflects a different social order,[44] while "critical" communication research in the United States—as far as it is identified with the dominant economic and political power - tends to operate on traditional, ideological grounds.

This is the historical juncture, where "left" research with its ambiguous existence on the boundary of liberalpluralist and Marxist theories of society, evolves into what I have called critical communication studies (or research) elsewhere. [45] Based on a theory of society, whose truth content is determined by "the manner in which it succeeds in lending a conceptual voice to social experience," to speak with Oskar Negt, "critical communication theory explores the present as a historical problem." [46] In fact, Negt argues that since late capitalism is "in its very dynamic core potentially Fascism," Critical Theory constitutes a historical specification that must be performed anew with every generation. This includes the instrumentalization of critical communication research as a radical articulation of "left" communication research in the United States.

In other words, what is left of "left" communication research is a critical examination of mass communicationin the Marxist sense of a critique of the social, economic, and political conditions of media. The focus rests on questions of class, gender, and race within relations of power, issues of access and participation, problems of ownership of the means of mass communication, and-in general-the process of democratization as a political agenda.

The future of "left" communication research is bound up in the future of intellectual work in self-defined democratic societies, like the United States. There is a considerable and long-lasting concern among intellectuals 
about their own predicament-which is their inability to act on what they know and foresee. What they have foreseen, however, exists as a critical observation about culture and cultural institutions in American society and provides a historical perspective on the role of the media; the observation reaches from the cultural crisis described by Lewis Corey in the 1930s to the workings of the "cultural apparatus" outlined by C. Wright Mills in the 1940s, or the "cultural mass" addressed by Daniel Bell in the 1970s and by more current writers, from Edward Said to Terry Eagelton. A new generation of "left" communication research must revitalize these traditions by addressing issues of class, power, ideology, and the nature of representation, in particular, to help push progressive thought beyond the traditional boundaries of American Pragmatism.

Indeed, "left" communication research has been the métier of politically engaged intellectuals, who respond in their specific sociopolitical roles to concerns about communication and democracy. Ralph Dahrendorf once described these intellectuals as the court jesters of modern society who must doubt the obvious, suggest the relativity of authority, and ask questions that no one else dares asking. The power of intellectuals lies in their freedom with respect to the hierarchy of the social order. They are, after all, qualified to speak on matters of culture and communication and engage society in a critique which utters uncomfortable truths, while breaking rules that govern the traditional insistence on disinterested, neutral, scientific, objective and discipline-bound scholarship. As Howard Zinn suggests, "if there is to be a revolution in the uses of knowledge. . . it will have to begin by challenging the rules which sustain wasting of knowledge."[47]

In an institutional framework of universities, "left "communication studies encourage self-reflection by offering theoretical insights and interpretive research strategies, while promoting the implementation of a democratic vision of communication and media. Such a task can only succeed as a socially conscious practice, however, when "left" communication research exposes the relations of power in the production of knowledge and the dissemination of information. Challenging the instrumental rationality of an administrative or corporate discourse reconfirms its own role as an historical agent of change. This role, however, and the location of "left" communication research, in general, raises new questions about its economics, in particular (e.g., its financial support in conservative institutions of higher learning with their own political agendas_and about the survival of "left" communication research within universities, in general. Such a survival is also threatened by a culture industry, whose tradition of inviting criticism, draws on "critical" observation for innovation in form and content. Accordingly, it will stand ready to co-opt cultural or political critique and, therefore, seriously compromise the work of "left" communication research.Finally, the short history of "left" communication research must be understood in the much longer historical context of a limited development of socialism in the United States, where it emerges from a failed attempt by the Old Left to offer real political and social alternatives to the working class, and from the failure of the New Left to survive its own agenda for change in America. Whether "left" communication research is seen as a new form of organizing resistance and challenging the dominant interpretation of social communication, or as an accumulation of oppositional expressions forging a new place for communication research as cultural production, still remains unclear.However, this cursory review of "left" communication research contains at least three useful insights from reading the "left." Theory must be connected to the specifics of experience, the practice of theorizing — as intellectual labor-must be translated into a public critique of communication and media in society, and communication research must ultimately serve the larger social and political goals of democratization. The latter insight may help restore a vision of utopia, that has all but disappeared from the lives of individuals, who are no longer convinced of being able to make a difference in the struggle over a meaningful existence. Mannheim once suggested that a "state of mind is utopian when it is incongruous with the state of reality within which it occurs." Focusing on the process of mass communication as a determinant of our social and political reality—with the aid of "left" communication research-will reveal the potential of creating alternative realities that 'tend to burst the bonds of the existing order."[48] It seems that "left" communication research has a choice at the beginning of the twenty-first century, based on its own history and the current economic conditions of universities and academic life in America: either to subsist in the decreasing margins of (mass) communication studies, whose own future rests with the demands of commercial interests, accompanied by a resurgence of traditional ideologies of teaching and research, or to move its critique collectively into the public arena, from professional meetings and the publication of new journals, to an alignment with progressive political initiatives. Whether the democratization of media and communication in the United States is more than a dream, however, is yet to be seen. 


\section{Endnotes}

\{An earlier version of this manuscript was presented at a Euricom Colloquium on "What is Left in Communication Research?” in Piran (Slovenia), September 17-20, 2003\}.

1. Good. (1989) introduces three distinctive approaches to power in communication theory through issues of integration and social control, following Lukes (1974)

2. Jansen(2002), 161. "Media-critical" theory-in the critical spirit of the Frankfurt School-is affiliated with "both (a) the importance of sociological analysis of formations and structures of power and knowledge,and (b) the significance of cultural analysis of the complex hegemonic and sometimes counterhegemonic processes. .."

\section{Mitchell,(1982), 613..}

4. Albion Small insists that socialism is a foreign "importation having little application to the American scene." Cited Hunt Page (1940), 140. Also see the 1906 essay by Werner Sombart(1976). Also, Samson (1933).

5. David Montgomery recalls that with the 1950s "American intellectual life was being inundated by a structuralist analysis of society and history that depicted as ludicrous any attempts by individuals or groups to change the world" or any analysis that saw change coming from enlightened leaders of society. In Marho, ed.(1983), 175.

6. There were no 'stable circles of Marxist sociologists in the academy that could anchor radical scholarship among left-oriented sociologists" before the 1960s. Instead, the liberal criticism of some sociologists appeared to be "left" in a "highly restricted spectrum of opinions in the academic discipline," according to Schwendinger and Schwendinger (1974), 563.

7. The inherent sentiment of a resurgent left tradition may have been expressed successfully much earlier by William Carlos Williams, who writes in 1925, "imagine stopping money making. Our whole conception of reality would have to be altered." Williams (1925).

8. In particular, Rogers, (1982). For a discussion of the failure to distinguish "critical" communication research see Jennifer Daryl Slack and Martin Allor (1983). For cultural differences between "critical" and mainstream communication research, see Lang (1979).

9. Among others: Lazarsfeld. (1970).

10. See Hardt (1992).

11. The notion of research is used here throughout this paper in the sense of inquiry, that is, as a broad, all-encompassing concept that includes empirical and philosophical (or quantitative and qualitative) methods of investigation.

12. Earlier in the United States, Josiah Warren had developed ideas regarding economic theory and individualist anarchism that predate the work of Marx and Joseph Proudhon, respectively. Warren argues in the 1840s that the solution to social order resides with the uses of mass communication, which he identifies with public influence. The process of communicationin its modern version of media practices-becomes a determinant of the social and political climate in society. Thus, he suggests that the simplification of printing methods, for instance, would help arouse public sentiment for order and against violations of individual rights. See: Warren ([1841]1952), 3-4.

13. For a detailed discussion of these and other authors, see Hardt(2001).

14. C. Wright Mills (1959), 92.

15. For a history of this period, see Murray (1955). Also Higham (1963).

16. Seldes (1937),Sinclair (1919), Villard (1923), Ickes (1939).

17. Dewey (1927).

18. Lippmann (1922).

19. Walter Rideout (1956) provides a full list of proletarian novels. Among the writers were John Dos Passos, Kenneth Burke, Granville Hicks, and Langston Hughes. See also Aaron (1961).

20. See Aaron (1961), 27. His book focuses on a number of radical writers and their contributions to the "left" intellectual tradition.

21. By the late 1960s, Linda Wiener Hausman (1967) identifies 506 articles appraising or criticizing the press.

22. The findings are published in: The Commission on Freedom of the Press (1947).

23. Eagleton (2000), 127.

24. Hobsbawm (1983),38.

25. Jesus Martin Barbero, who is one of the "fathers" of this development, also includes "Luis Ramiro Beltrán in Bolivia, Mattelart in Chile, Pasqualli in Venezuela, Mario Caprún the Uruguayan, Hector Schmuckler in Argentina, Bordenabe from Paraguay, amongst others." He adds, " Publications like 'Lenguajes' and 'Comunicación y Cultura' are practically political projects per se.” (1999, May) 
26. From the editorial statement, Inter-Asia Cultural Studies (1999).

27. Gouldner (1970), 400.

28. Thompson (1983(),10.

29. Buhle, (1987), 164.

30. Schwendinger and Schwendinger (1974), 563.

31. Lazarsfeld (1972).

32. See Gitlin (1978).

33. UDC held its 1993 annual conference at the Latin American film school near Havana, Cuba.

34. Its editors claim that "varied theoretical and methodological perspectives were asserting themselves as "critical studies" within communication". . . but a single definition was "to be both unrealistic and unproductive for the good of the field." Instead, the journal sought to encourage a "dialectic pluralism." Avery and Eason, (1991), 3-4.

35. Edited by Elihu Katz, John Durham Peters, Tamar Liebes, and Avril Orloff (2003).

36. Becker and Horowitz (1972).

37. Sorokin (1956); Mills, (1959); Birnbaum (1971). Also: O’Neill (1972)
38. Recently, Javnost-The Public (X, 2003, 2) published the results of a colloqium on "Communication in pre-20th Century Thought," for instance, which demonstrates the long-standing debates regarding communication, media, and effects in society.

39. Similarly, the historical circumstances of the rise of British Cultural Studies become important sources for understanding the relations of culture, communication, and society.

40. Grossberg (1991).

41. See the work of Tom Guback, but also Vincent Mosco, Robert McChesney, Eileen Meehan, or Janet Wasko, among others.

42. Hardt (1992), 148-49.

43. (1990). The volume contains a number of his important essays.

44. Following Mannheim (1936).

45. Hardt (1998.).

46. Negt (1980).

47. Zinn, (1970), 9.

48. Mannheim (1936),192-93.

\section{References}

Aaron, Daniel. 1961. Writers on the Left. New York: Harcourt Brace and World.

Avery, Robert K. and David Eason, eds. 1991. Introduction. Critical Perspectives on Media and Society. New York: Guilford Press.

Barbero, Jesus Martin Barbero. 1999. The Communication Initiative. (May interview) Retrieved from http://www. comminit.com/interviews_archives8.html.

Becker, Howard S. and Irving Louis Horowitz. 1972. July. "Radical Politics and Sociological Research: Observations on Methodology and Ideology." American Journal of Sociology 78:235-242.

Bigham, John. 1963. Strangers in the Land: Patterns of American Nativism, 1860-1925. New York: Atheneum.

Birnbaum, Norman. 1971. Toward a Critical Sociology. New York: Oxford University Press.

Buhle, Paul. 1987. Marxism in the USA. From 1870 to the Present Day. London:Verso.

Carlos Williams, William. 1925. In the American Grain. New York: Boni.

Commission on Freedom of the Press. 1947. "A Free and Responsible Press."A Report on Mass Communication: Newspapers, Radio, Motion Pictures, Magazines and Books. Chicago: University of Chicago Press.
Dewey, John. 1927. The Public and its Problems. New York: Henry Holt.

Eagleton, Terry. 2000. The Idea of Culture. Oxford: Blackwell. Garnham, Nicholas. 1990. "Capitalism and Communication." Global Culture and the Economics of Information. London: Sage.

Gitlin, Todd. 1978. "Media Sociology: The Dominant Paradigm." Theory and Society 6(2):205-253.

Good, Leslie T. 1989. "Power, Hegemony, and Communication Theory." In Cultural Politics in Contemporary America, edited by Ian Angus and Sut Jhally. New York: Routledge.

Gouldner, Alvin W. 1970. The Coming Crisis of Western Sociology. New York: Basic Books.

Grossberg, Lawrence. 1991. "Strategies of Marxist Cultural Interpretation." In Critical Perspectives on Media and Society, edited by Robert K. Avery and David Eason. New York: Guilford.

Hardt, Hanno. 1992. "Critical Communication Studies." Communication, History and Theory in America. London: Routledge.

Hardt, Hanno. 1998. "Interactions." Critical Studies in Communication, Media, and Journalism. Boulder, CO: Rowman and Littlefield. 
Hardt, Hanno. 2001. Social Theories of the Press: Constituents of Communication Research, 1840s to 1920s. Boulder,CO: Rowman and Littlefield.

Hobsbawm, Eric. 1983. Visions of History. Edited by Maho. New York: Pantheon.

Hunt Page, Charles. 1940. Class and American Sociology. From Ward to Ross. New York: Dial Press.

Ickes, Harold. L. 1939. America's House of Lords. An Inquiry into Freedom of the Press. New York: Harcourt, Brace.

Inter-Asia Cultural Studies 1:1 1999.

Jansen, Sue Curry. 2002. Critical Communication Theory. Boulder,CO: Rowman and Littlefield.

Katz, Elihu, John Durham Peters, Tamar Liebes, and Avril Orloff. 2003. Canonic Texts in Media Research. Cambridge: Polity.

Lang, Kurt. 1979. “The Critical Functions of Empirical Communication Research: Observations on GermanAmerican influences." Media, Culture and Society 1:83-96.

Lazarsfeld, Paul F. 1970. Main Trends in Sociology. New York: Harper and Row.

Lazarsfeld, Paul. 1972. "Remarks on Administrative and Critical Communications Research.” Zeitschrift für Sozialforschung 9(1):2-16.

Lippmann, Walter. 1922. Public Opinion. New York: Harcourt, Brace.

Lukes, Steven. 1974. Power. A Radical View. London: Macmillan.

Mannheim, Karl. 1936. Ideology and Utopia. New York: Harcourt, Brace and World.

Marho, ed. 1983. Visions of History. New York: Pantheon.

Mills, C. Wright. 1959. The Sociological Imagination. New York: Oxford University Press.

Mitchell, W. J. T. 1982. "Critical Inquiry and the Ideology of Pluralism.” Critical Inquiry 8:613.

Murray, Robert K. 1955. Red Scare: A Study in National Hysteria, 1919-1920. Minneapolis: University of Minnesota Press

Negt, Oskar. 1980. "Mass Media: Tools of Domination or Instruments of Liberation? Aspects of the Frankfurt School's Communications Analysis." In The Myths of Information: Technology and Postindustrial Culture, edited by Kathleen Woodward. Madison, WI: Coda Press,
O’Neill, John. 1972. Sociology as a Skin Trade: Essays towards a Reflexive Sociology. New York: Harper Torchbooks.

Rideout, Walter. 1956. The Radical Novel in the United States, 1900-1954. Cambridge, MA: Harvard University Press.

Rogers, Everette. 1982. "The Empirical and the Critical Schools of Communication Research." In Communication Yearbook 5, edited by M. Burgoon. New Brunswick, NJ: Transaction Books.

Samson, Leon. 1933. Towards a United Front: A Philosophy for American Workers. New York: Farrar and Rinehart.

Schwendinger, Herman and Julia R. Schwendinger. 1974. The Sociologists of the Chair. A Radical Analysis of the Formative Years of North American Sociology, 1883-1922. New York: Basic Books.

Seldes, George. 1937. Freedom of the Press. Garden City, NY: Garden City Publishing.

Sinclair, Upton. 1919. The Brass Check. A Study of American Journalism. Pasadena, CA:published by author.

Slack, Jennifer Daryl and Martin Allor. 1983. "The Political and Epistemologicval Constituents of Critical Communication Research." Journal of Communication 33(3):208-18.

Sombart, Werner. 1976. Why is there No Socialism in the United States? White Plains, NY: Sharpe.

Sorokin, Pitirim. 1956. Fads and Foibles in Modern Sociology and Related Sciences. Chicago: Regnery.

Thompson, E.P. 1983. Visions of History. Edited by Maho. New York: Pantheon.

Villard, Oswald Garrison. 1923. Some Newspapers and Newspapermen. New York: A.A. Knopf.

Warren, Josiah. [1841] 1952. Manifesto. Berkeley Heights, NJ: Oriole Press.

Wiener Hausman, Linda. 1967. "Criticism of the Press in U.S. Periodicals, 1900-1939. An Annotated Bibliography." Journalism Monographs 4.

Zinn, Howard. 1970. The Politics of History. Boston: Beacon Press. 
